Human Rights Law Review 10:3 (C) The Author [2010]. Published by Oxford University Press. All rights reserved. For Permissions, please email: journals.permissions@oxfordjournals.org doi:10.1093/hrlr/ngq022

\title{
Beyond Bosphorus:The European Court of Human Rights' Case Law on the Responsibility of Member States of International Organisations under the European Convention on Human Rights
}

\author{
Tobias Lock*
}

\section{Introduction}

This note is an attempt to provide an overview of and critically analyse the European Court of Human Rights' (ECtHR or 'Court') most recent case law on the responsibility of member states of international and supranational organisations. The focus will be on the Court's application of its Bosphorus decision in later cases and how it distinguished the Bosphorus case law from the more recent Behrami decision.

The Bosphorus case was concerned with the impounding of an aircraft by Ireland on the basis of an obligation in a European Communities (EC) regulation, which itself was based on a Resolution by the United Nations (UN) Security Council. ${ }^{1}$ Because the aircraft was impounded by Irish authorities on Irish territory, the ECtHR had no difficulty finding that the applicant company was within Ireland's jurisdiction according to Article 1 of the European

*DAAD/Clifford Chance lecturer at the Faculty of Laws, University College London (t.lock@ucl .ac.uk). I would like to thank the editors for their helpful comments and Jennifer Hegarty-Owens for proofreading this article.

1 Bosphorus Hava Yollari Turizm ve Ticaret Anonim Şiketi v Ireland 2005-VI; 42 EHRR 1 (Bosphorus). 
Convention on Human Rights (ECHR or 'Convention') so that Ireland could be held responsible for impounding the aircraft and any violation of the ECHR that arose therefrom. The ECtHR then famously held that the Contracting Parties to the ECHR are not prohibited from transferring sovereign power to an international organisation but that they remain responsible for all acts and omissions of their organs 'regardless whether the act or omission was a consequence of domestic law or of the necessity to comply with international legal obligations.' ${ }^{2}$ The Court went on to state that as long as the international organisation is considered to protect fundamental rights... in a manner which can be considered at least equivalent to that for which the Convention provides' the Court will presume that a State has acted in compliance with the Convention, where the state had no discretion in implementing the legal obligations flowing from its membership of the organisation. ${ }^{3}$ That presumption can, however, be rebutted where the protection in the particular case is regarded as "manifestly deficient'. ${ }^{4}$ The Court thus introduced a two-stage test: at the first stage the Court examines whether an organisation provides an equivalent protection, which causes the presumption to apply. At the second stage the Court examines whether that presumption has been rebutted in the concrete case before it because of a manifest deficit in the protection of human rights. In the Bosphorus case, the ECtHR considered the human rights protection afforded by the European Union to be equivalent to that of the Convention, so the presumption applied. The Court saw no reason why the protection in that case could be considered manifestly deficient. ${ }^{5}$ Therefore, the ECtHR held that the interference with the applicant's property rights protected by Article 1 of Protocol No. 1 of the ECHR was justified.

In Bosphorus, the Court offered an important clarification to its earlier ruling in Matthews $v$ United Kingdom. ${ }^{6}$ Matthews was the first case in which the Court held that a Member State of the European Union was in breach of the Convention brought about by EU law. The violation was rooted in the EC Act on Direct Elections of 1976, a treaty concluded by all the EU Member States at the time. The Court in Matthews expressly stated:

The Convention does not exclude the transfer of competences to international organisations provided that Convention rights continue to be 'secured'. Member States' responsibility therefore continues even after such a transfer. ${ }^{7}$

2 Ibid. at para. 153.

3 Ibid. at paras 155 and 156.

4 Ibid. at para. 156.

5 Ibid. at paras 159-66.

6 1999-I; 28 EHRR 361.

7 Ibid. at para. 32. 
In contrast to Matthews, the violation in Bosphorus could not be directly found in EU primary legislation, i.e. the treaties, but in secondary legislation, i.e. an act adopted by the organisation itself. ${ }^{8}$ The main difference with regard to the protection of human rights is that acts of secondary legislation can be challenged before the European Court of Justice (ECJ). While Matthews established that the Member States of the EU remain generally accountable for human rights violations caused by the law of the European Union, the Bosphorus decision was seen as an attempt to accommodate the autonomy of the EU legal order within the premise set out in Matthews. ${ }^{9}$ Furthermore, it was submitted that the judgment had to be viewed in the specific context of an EU accession to the Convention ${ }^{10}$ and of the potentially overlapping jurisdiction between the ECtHR and the ECJ. ${ }^{11}$

The Bosphorus decision left a number of questions unanswered, some of which this note will attempt to answer in light of the latest case law in which Bosphorus was either applied or distinguished. The first open point was whether the Bosphorus presumption would also apply where there was no action or omission by a Member State but only action by EU institutions. ${ }^{12}$ It was also unclear when exactly the protection granted by an international organisation would be considered 'manifestly deficient' and how rigorous the ECtHR's scrutiny would be. Would the presumption also apply where the national court dealing with the case did not make a preliminary reference to the ECJ under Article 267 of the Treaty on the Functioning of the European Union (TFEU; former Article 234 of the Treaty of the European Community)? ${ }^{13}$ A further point was how much (if any) discretion in implementing its legal obligations flowing from its membership in an international organisation a Member State of the EU can enjoy before the presumption will cease to apply. ${ }^{14}$

\section{The Requirement of a Domestic Act}

\section{A. The Decisions}

After Bosphorus it seemed that under the Convention a Member State of an international organisation was generally responsible for acts and omissions

8 Ibid. at para. 157.

9 Costello, "The Bosphorus Ruling of the European Court of Human Rights: Fundamental Rights and Blurred Boundaries in Europe', (2006) 6 Human Rights Law Review 87 at 88.

10 Ibid. at 89.

11 Ibid. at 119.

12 It was suggested that the presumption should apply in such a case as well, see Winkler, "Die Vermutung "äquivalenten” Grundrechtsschutzes im Gemeinschaftsrecht nach dem Bosphorus-Urteil des EGMR', [2007] Europäische Grundrechtezeitschrift 641 at 653-4.

13 Peers, 'Bosphorus European Court of Human Rights', (2006) 2 European Constitutional Law Review 443 at 452.

14 Ibid. at 453. 
required of that organisation and could only escape that responsibility where the presumption applied and was not rebutted. However, in the case of Behrami, the Grand Chamber of the ECtHR introduced an important distinction. ${ }^{15}$ The case concerned the responsibility of certain Member States of the Council of Europe for the action of their troops that formed part of the security presence in Kosovo (KFOR), which had been established by a resolution of the UN Security Council. ${ }^{16}$ Could acts and omissions by these troops still be attributed to the Convention Parties under Article 1 of the ECHR? That provision requires that the applicants were 'within [the State's] jurisdiction'. The ECtHR held that the acts and omissions of these troops were attributable to the United Nations, not the Contracting Party concerned, because the Security Council retained ultimate control over them. ${ }^{17}$ The Court went on to distinguish the case from the Bosphorus case. There the measure had been carried out by the respondent State (Ireland) on its territory, so the Court did not consider that its jurisdiction ratione personae was an issue, even though the source of the respondent State's action was an EU regulation. ${ }^{18}$ In the case of Behrami, however, the Court held that the actions and omissions could not be attributed to the respondent States. They did not take place on their territory or by virtue of a decision of their authorities. ${ }^{19}$ The Court also pointed to the 'fundamental distinction' between the EU and the UN and accorded great significance to the latter organisation's universal jurisdiction, which was 'fulfilling its imperative collective security objective. ${ }^{20}$

In Beric $v$ Bosnia and Herzegovina, ${ }^{21}$ the fourth section of the Court applied the approach taken in Behrami. The facts of both cases were very similar. The applicants had been removed from their public offices in the administration of the respondent State by the High Representative in Bosnia and Herzegovina, the holder of a position established by the Dayton Peace Agreement ${ }^{22}$ and appointed by a UN Security Council Resolution. ${ }^{23}$ The Court concluded that the High Representative's actions were attributable to the UN and not to the respondent State. As in Behrami, the Court explicitly contrasted the case with the Bosphorus decision. However, this time it did not rely on the fact that the

15 Behrami and Behrami v France; Saramati v France, Germany and Norway 45 EHRR SE10.

16 UNSC Res. 1244, 10 June 1999, S/RES/1244.

17 Behrami, supra n. 15 at paras $132-41$. This finding was heavily criticised by commentators, mainly because the question of whether an act or omission is attributable to the UN does not determine whether it is (also) attributable to the member state; cf. Sari, 'Jurisdiction and International Responsibility in Peace Support Operations: The Behrami and Saramati Cases', (2008) 8 Human Rights Law Review 151 at 159; and 'Case Comment on Behrami and Saramati' (2007) European Human Rights Law Review 698 at 702.

18 Behrami, supra n. 15 at para. 151.

19 Ibid.

20 Ibid.

2146 EHRR SE6.

22 General Framework Agreement for Peace in Bosnia and Herzegovina, S/1995/999; Annex 10 of the Agreement sets out the mandate of the High Representative.

23 UNSC Res. 1031, 15 December 1995, S/RES/1031 (1995). 
measures in Beric were not carried out within the territory of a Contracting Party (because they were) but rather that the measures complained of did not require any implementation by the domestic authorities. ${ }^{24}$ Referring to its reasoning in Behrami, the Court declared the case inadmissible ratione personae.

The Court has extended its approach in Behrami beyond cases involving the UN, to labour disputes between international organisations and their employees. In Boivin v 34 Member States of the Council of Europe, ${ }^{25}$ an employee of the international organisation Eurocontrol, of which the 34 respondent States were members, complained of his removal from the post of head accountant at the organisation's Institute of Air Navigation Services. Having been unsuccessful with an internal complaint, the applicant brought a case to the competent International Labour Organisation Administrative Tribunal, where he also was unsuccessful. The ECtHR distinguished the case from Bosphorus because "[a]t no time did [the respondent states] intervene directly or indirectly in the dispute, and no act or omission of those States or their authorities can be considered to engage their responsibility under the Convention, ${ }^{26}$ It held that the applicant's complaints were directed against the decision of the Administrative Tribunal and not against a measure by the respondent States. As there was no involvement of the respondent States in the functioning of the Administrative Tribunal, the Court applied the reasoning of Behrami and held the case to be inadmissible ratione personae as the actions could not be attributed to the respondent States.

Essentially the same reasoning was applied in the case of Connolly $v 34$ Member States of the Council of Europe, which dealt with a labour dispute between an employee of the European Commission and the EC. ${ }^{27}$ The applicant took his complaint to the Court of First Instance and to the ECJ where his request to submit written observations on the opinion of the Advocate General was denied. He then took a case against all the (then) Member States to Strasbourg claiming a violation of Article 6 of the ECHR. As in Boivin, the Court stated that in reality the complaint was directed against the decisions by the EU courts and that at no time did the respondent States directly or indirectly intervene. Thus the Court declared the complaint inadmissible ratione personae.

The same substantive question was raised only a few weeks later in Kokkelvisserij $v$ The Netherlands. ${ }^{28}$ The applicant had been granted a licence for cockle fishing in the North Sea by the Dutch authorities. This licence was

24 Supra n. 21 at para. 29.

25 Application No. 73250/01, Admissibility Decision of 9 September 2008.

26 Ibid.

27 Application No. 73274/01, Admissibility Decision of 9 December 2008; confirmed in Beygo v 46 Member States of the Council of Europe, Application No 36099/06, Admissibility Decision of 16 June 2009; and Rambus Inc. v Germany, Application No 40382/04, Admissibility Decision of 16 June 2009. 
objected to by a Dutch environmental organisation, which led to domestic proceedings in the Dutch administrative court. The applicant appeared as an interested party in these proceedings. Because the interpretation of the European Community's Habitat Directive ${ }^{29}$ was at issue, the Dutch court made a reference under Article 234 of the EC Treaty (now Article 267 TFEU) to the ECJ. As in Connolly, the applicant requested permission to submit a written response to the Advocate General's opinion in the case. That request was denied by the ECJ ${ }^{30}$ and the applicant took the case to the ECtHR. In contrast to Connolly, the ECtHR held that the denial could be imputed to the Netherlands. It expressly distinguished the case from Boivin as the applicant's complaint in Kokkelvisserij was based on an intervention by the ECJ actively sought by a domestic court in proceedings pending before it. It cannot therefore be found that the respondent party is in no way involved. ${ }^{31}$ The Court then quoted and applied the Bosphorus case and held that the presumption could not be rebutted because the protection of Convention rights was not manifestly deficient. ${ }^{32}$

On the same day as Connolly, the same section of the ECtHR decided the case of Biret $v 15$ Member States of the European Union. ${ }^{33}$ Biret was an importer of beef from the USA to the European Union. In 1988 the European Union adopted two directives prohibiting certain hormones in beef, which led to an embargo against the importation of US beef. Because of the embargo, the applicant company became insolvent in 1995. In 1998, the Appellate Body of the World Trade Organisation (WTO) held that the embargo against US beef was incompatible with WTO law. On that basis, the applicant company tried to recover damages from the European Community, but failed. ${ }^{34}$ Biret made two distinct complaints to the ECtHR. It claimed a violation of its procedural rights enshrined in Articles 6 and 13 of the ECHR because it did not have a chance to directly challenge the EC directives in the Community courts. The company claimed that its property rights guaranteed by Article 1 of Protocol No. 1 had been infringed because the measures had deprived the company of its business. The Biret decision is instructive as it confirms both the approaches taken in Behrami and Bosphorus. With regard to the claims based on Biret's procedural rights under Articles 6 and 13, the Court held that they related solely to deficits in the judicial protection offered by the EC and were thus not attributable to the Member States. ${ }^{35}$ When discussing the alleged infringement

Council Directive 92/43/EEC of 21 May 1992 on the conservation of natural habitats and of wild fauna and flora, [1992] OJ L 206/7.

30 ECJ, Case C-127/02 Waddenvereniging and Vogelsbeschermingvereniging [2004] ECR I-7405.

31 Kokkelvisserij, supra n. 28 at para. 3.

32 It is noteworthy that the Court's decision neither refers to Connolly nor to Biret.

33 Application No. 13762/04, Admissibility Decision of 9 December 2008.

34 ECJ, Case C-93/02 P Biret International v Council [2003] ECR I-10497.

35 Biret, supra n. 33 at para. 1. 
of Biret's property rights, the Court held that France could generally be held responsible as Biret was affected by measures implementing the embargo taken by France. The Court then applied its Bosphorus presumption in favour of the Community legal order and stated that it could not find a manifestly deficient protection of human rights in the present case. Therefore the application was held to be manifestly ill-founded and declared inadmissible.

The cases discussed above suggest that the Court has applied the following distinctions. The Bosphorus principle applies where a Contracting Party's authorities have acted, either by implementing a decision of an international organisation (Bosphorus) or by making a reference to that organisation's court (Kokkelvisserij). In the former case, applications are held inadmissible ratione personae as they are directed, in effect, against an act of an international organisation, which is not a party to the Convention. In accordance with the Behrami case law, the Court finds that the applicant was not within the jurisdiction of the respondent State.

In the latter type of case the Bosphorus presumption applies. The Court must examine whether that presumption has been rebutted which requires a manifest deficiency in the human rights protection in the actual case. Where the presumption is not rebutted, the Court will declare the case inadmissible because it is manifestly ill-founded.

However, in the most recent decision of Gasparini v Italy and Belgium, ${ }^{36}$ the second section of the Court offered a further distinction. The subject of the case was another labour dispute, this time between the North Atlantic Treaty Organisation (NATO) and an employee, Gasparini, regarding an increase in NATO's pension levy. The applicant filed a complaint with the NATO Appeals Board (NAB). As the NAB's sessions are not held in public, the applicant claimed a violation of Article 6 of the ECHR. In that case, the Court offered a new reading of the Boivin, Connolly and Kokkelvisserij cases. As Gasparini concerned a labour dispute, one would have expected the Court to declare the application inadmissible ratione personae. However, it distinguished the cases of Boivin and Connolly from the case of Gasparini. While in the earlier cases the complaints were directed against a particular decision of an organ of an organisation, in Gasparini the complaint was directed against a structural deficit in the internal mechanism for conflict resolution. Thus the Court went on to examine whether there was a manifest deficit in the protection of fundamental rights, which it could not detect. 


\section{B. Comment}

After Bosphorus, it was speculated that the Court would apply the Bosphorus presumption a fortiori where it would have to decide a case in which there was no implementing action by a Member State. In Connolly, however, the Court decided to go even further and made it clear that it will not consider cases where there was no action by a Contracting Party. Domestic action can either consist of an implementing act, as was the case in Bosphorus, or a preliminary reference by a domestic court to the ECJ, as was the case in Kokkelvisserij. In such cases the Court will generally hold the respondent State responsible and apply the Bosphorus principle. In cases where only the international organisation acted (and none of the Contracting Parties), the Court will apply the Behrami approach, unless the complaint is directed against a 'structural deficit in the internal mechanism for conflict resolution. ${ }^{37}$ This warrants some comment.

It is remarkable that the Court extended the Behrami approach beyond cases where the act or omission by the respondent States' officials was attributable to the United Nations. In both Behrami and Beric, the Court emphasised that the actions or omissions complained of happened in the context of a UN Security Council Resolution. When distinguishing the Bosphorus case, the Court stressed that the great majority of Contracting Parties had joined the UN before becoming a party to the Convention. ${ }^{38}$ Moreover, the Court specifically mentioned Article 103 of the UN Charter, which provides that the obligations originating in the Charter, including the obligations flowing from Security Council Resolutions, prevail over other international legal obligations. ${ }^{39}$ And finally, the Court stated:

Since operations established by UNSC Resolutions under Chapter VII of the UN Charter are fundamental to the mission of the UN to secure international peace and security and since they rely for their effectiveness on support from member states, the Convention cannot be interpreted in a manner which would subject the acts and omissions of Contracting Parties which are covered by UNSC Resolutions and occur prior to or in the course of such missions, to the scrutiny of the Court. ${ }^{40}$

This statement makes it clear that the solution found in Behrami was tailored to the specific context of a conflict between Contracting Parties' obligations under the Convention and under the law of the United Nations, which, according to Article 103 of the UN Charter, is supreme. The Court expressly relied on 
this passage in Beric. ${ }^{41}$ Furthermore, all Member States of the European Union are bound by the ECHR, which is not the case for all members of the United Nations. Thus, there is nothing in Behrami to suggest that the solution found in that case should be extended to obligations flowing from the Contracting Parties' membership in other organisations. This seems to have also been the position of the Court as it explicitly pointed out the difference between the EU, to which Bosphorus applied, and the UN, which acted as an organisation of universal jurisdiction fulfilling its imperative collective security objective. ${ }^{42}$

Moreover, it is submitted that the extension is against the very spirit of the Court's judgments in Matthews and Bosphorus. In those cases, the Court made it clear, that Contracting Parties cannot escape their responsibility under the Convention by transferring sovereign rights to international organisations. They remain responsible for violations of Convention rights originating in the organisation's constituent treaties (Matthews) and violations of Convention rights originating in acts or omissions by the organs of the organisation (Bosphorus). This pro-human rights approach avoided a circumvention of Convention obligations by Contracting Parties. Even if the States allowed an international organisation to exercise sovereign rights in their place, they would be held responsible under the Convention for any violation arising therefrom. Where State action is undertaken by international organisations, this should not be immune from the supervision of the Court. ${ }^{43}$ The novel application of the Behrami approach beyond the context of the United Nations makes exactly such circumvention possible. In this respect, the Court's statement that the application in Connolly was essentially directed against the decision of the Administrative Tribunal is hardly convincing. The same argument could have been made in Bosphorus where the application was in reality directed against the EU regulation or even the resolution of the UN Security Council on which the regulation was based. ${ }^{44}$

Of course, it can be argued that purely internal disputes, such as labour disputes between international organisations and their employees, do not involve an exercise of sovereign powers by the organisation and thus should not be subject to review by the ECtHR. However, I suggest that the approach taken in older cases involving labour disputes between an international organisation and their employees provides a preferable solution. In the cases of Beer and Regan $v$ Germany ${ }^{45}$ and Waite and Kennedy v Germany, ${ }^{46}$ the Court found that

41 Supra n. 21 at para. 29.

42 Behrami, supra n. 15 at para. 151.

43 This was pointed out by Judge Ress in his concurring opinion to the Bosphorus case, supra n. 1 at para. 1 .

44 Peers, supra n. 13 at 453, rightly pointed out that even the distinction between Bosphorus and Matthews is not that easy.

4533 EHRR 54.

46 1999-I; 30 EHRR 261. 
the respondent State was justified in granting immunity from suit to the European Space Agency because that agency offered a reasonable alternative to protect its employees' rights, namely its own independent appeals procedure. $^{47}$ By carrying out a substantive test, this approach clearly avoided any potential violation of the rights of the employees. In Connolly, the Court distinguished the cases just mentioned arguing that the applicants in the former cases brought their case before a domestic court and not before an internal mechanism for conflict resolution as in Connolly. ${ }^{48}$ Thus the Court relied on the absence of a domestic act, which, for the reasons mentioned above, cannot justify a differentiation in the human rights protection guaranteed by the Convention. One may wonder whether the Court would have followed the same route had the issue in the case not been the much-debated question of the right to respond to the Advocate General's opinion, ${ }^{49}$ but a clear violation of Convention rights, for instance a complete denial of judicial review.

The Gasparini judgment is significant for several reasons. First, it extends the Bosphorus presumption to an organisation beyond the EU. Second, the decision can be regarded as an attempt to mitigate the effects of the Court's previous decisions. It offers a very restrictive reading of the Connolly and Boivin cases in that it distinguishes between actual decisions by the organisation and deficiencies in the protection of fundamental rights, rooted in a structural deficit of the internal mechanism for conflict resolution. Surprisingly, the Court then applied the Bosphorus principle, which in the EU context is only relevant in the case of secondary EU law. The main reason why the Bosphorus presumption does not apply to violations originating in the treaty itself is that there is no judicial remedy against them under EC law. The ECJ only has jurisdiction to declare acts of secondary EU law to be incompatible with the EU's founding treaties and fundamental rights recognised in the EU's Charter of Fundamental Rights or as general principles of EU law. Considering that there is no possibility to challenge the Staff Rules of NATO within NATO, the Court ought to have applied the Matthews doctrine whereby it has full jurisdiction to review whether the rule complained of is in violation of the Convention.

Third, the Gasparini judgment seems to introduce a new rationale for the Bosphorus presumption. The Court stated that it would have to determine in reality if the defendant States, when joining NATO, were able to consider in good faith that the internal mechanism for the solution of labour conflicts

47 Beer and Regan, supra n. 45 at para. 54; and ibid. at para. 73.

48 This distinction was expressly confirmed in Lopez Cifuentes v Spain, Application No. 18754/06, Admissibility Decision of 7 July 2009, at para. 31.

49 On this question cf. ECJ, Case C-17/98 Emesa Sugar [2000] ECR I-665; Emesa Sugar v The Netherlands, Application No.62023/00, Admissibility Decision of 13 January 2005; and Vermeulen v Belgium 1996-I; 32 EHRR 313. 
was not in flagrant contradiction to the Convention. ${ }^{50}$ This suggests that it would no longer be necessary that the human rights protection existing within an international organisation is actually equivalent to that under the Convention at the time of the alleged violation, but rather that the test is whether at the moment of joining an organisation, Convention Parties acted in good faith. The crucial time for the Court's assessment thus seemed to be the moment of accession to NATO. However, this is in contradiction to Bosphorus, where the Court held:

State action taken in compliance with such legal obligations is justified as long as the relevant organization is considered to protect fundamental rights, as regards both the substantive guarantees offered and the mechanisms controlling their observance, in a manner which can be considered at least equivalent to that for which the Convention provides. ${ }^{51}$

This implies that the crucial time for the Court's assessment of whether the presumption applies or not must be the time of the alleged violation and not the time of accession to the organisation. Whether a Member State had considered that the protection offered would not be in violation of the Convention should thus not determine the applicability of the presumption.

Furthermore, it is submitted that the Court's reason for distinguishing Connolly is not convincing. Whereas in the Boivin case the applicant had been removed from his post by an organ of Eurocontrol acting independently of Member States, in Connolly the reason for the ECJ's decision not to allow the applicant to respond to the opinion of the Advocate General was based on the Statute of the ECJ and its Rules of Procedure (neither of them provide for such a possibility). Therefore, the Connolly case concerned a structural deficit rather than an independent decision by an organ of an international organisation. It therefore resembles Gasparini rather than Boivin. Moreover, in drawing this distinction, the ECtHR failed to consider Biret. In that case the Court held that the lack of access to a court or tribunal before which directives could directly be challenged was due to an alleged deficit in the Community judicial order and thus could not be attributed to the respondent States. ${ }^{52}$ The Court did not consider that the respondent States agreed to that deficit when concluding the EC Treaty, so that this alleged violation is clearly attributable to the Member States under Matthews.

What is remarkable about Gasparini, is that it was the first judgment in which the Court generally held Convention Parties responsible for an act by

50 'Pour la Cour, il lui faut en réalité déterminer si, au moment où ils ont adhéré à l'OTAN et lui ont transféré certains pouvoirs souverains, les Etats défendeurs ont pu, de bonne foi, estimer que le mécanisme de règlement des conflits du travail interne à l'OTAN n'était pas en contradiction flagrante avec les dispositions de la Convention.' See Gasparini, supra n. 36.

51 Bosphorus, supra n. 1 at para. 155 [emphasis added].

52 Biret, supra n. 33 at para. 1. 
an international organisation which has members that are not bound by the Convention. The USA and Canada are not bound by the Convention, but the alleged procedural deficit in the Staff Rules of NATO would be attributable to them also. If the Court had found a violation of the Convention, it would thus have held these countries indirectly responsible for the violation of a human rights treaty to which they are not parties. Furthermore, the Court extended the Bosphorus presumption to an organisation that is not the EU. Bosphorus was very much regarded as recognition of the EU's supranational character and the high level of human rights protection afforded by the ECJ. The extension of Bosphorus to NATO is therefore surprising.

\section{Equivalent Protection and Manifest Deficit}

\section{A. The Requirement of a Previous ECJ Decision}

One of the questions left open after the Bosphorus judgment was how the Court would deal with the requirement of a manifest deficiency in the protection of Convention rights. In that case the Court held that such a deficiency could not be found because "there was no dysfunction of the mechanisms of control of the observance of Convention rights, ${ }^{53}$ In so finding, the Court explicitly relied on the previous preliminary ruling of the ECJ in the matter. The case of Coopérative des Agriculteurs de Mayenne v France ${ }^{54}$ however suggests that a previous ruling is not always necessary. In that case the applicant farming cooperatives complained of an infringement of a number of their Convention rights because the French National Dairy Board requested the payment of a certain sum of money because the applicants had exceeded their milk quotas. The legal bases for these milk quotas were three detailed Community regulations, which provided for a levy to be paid by the producer where the quotas were exceeded. The French Conseil d'Etat did not make a reference to the ECJ but decided the case based on these Community regulations. The ECtHR nonetheless applied the Bosphorus principle and held that there was no manifest deficiency in the protection of the applicants' Convention rights. One could argue that this ruling is astonishing because the Community judicial system, the existence of which was one of the main reasons why the Court found the protection offered to be equivalent, was not involved in the actual case. On the other hand, the fact that the Conseil d'Etat did not make a reference to the ECJ in the present case does not necessarily mean that fundamental rights were not protected. The domestic courts are part of the Community legal system in the wider sense. They are bound to

53 Bosphorus, supra n. 1 at para. 166.

54 Application No. 16931/04, Admissibility Decision of 10 October 2006. 
apply Community law and respect its supremacy over domestic law. Thus the domestic courts are required to examine whether a piece of Community legislation violates fundamental rights and, should the situation arise, make a reference to the ECJ. Therefore, the Court was correct in not finding a manifest deficiency in the lack of a reference alone. However, it would have been preferable, for the sake of clarity, if the Court had addressed this question. Instead, it remained completely silent on this point.

\section{B. The Need to Plead a Manifest Deficit}

In Boivin, the Court made it clear that an applicant must establish or at least allege that the protection of fundamental rights is not equivalent to that of the Convention system. As the applicant had failed to do so, it did not examine whether the protection was manifestly deficient in that case. These remarks must, of course, be considered to have been made obiter dicta as the Court then ruled that the action was not attributable to the respondent States. In Gasparini the Court repeated this statement and it can therefore be concluded that the Court requires that an applicant at least claims either that the protection offered by the organisation is not equivalent or that it is manifestly deficient. This means that the Court will not examine this question proprio motu. Rather, the burden of proof for the existence of a manifest deficit is on the applicant.

\section{The Scrutiny Carried Out by the ECtHR}

A further issue is the level of scrutiny carried out by the ECtHR. In Bosphorus, the Court was very quick to conclude that the protection offered by the EC in that case was not dysfunctional and thus not manifestly deficient. ${ }^{55}$ The Court merely pointed to the nature of the interference, the general interest pursued and the ruling of the ECJ. This created the impression that the Court's test would be rather superficial, especially in light of the cursory proportionality test carried out by the ECJ in its own Bosphorus ruling. ${ }^{56}$ It was thus suggested that the more impressive human rights analysis in the Advocate General's opinion might have saved the ECJ's decision from greater Strasbourg scrutiny. ${ }^{57}$ The first time the Court applied the Bosphorus test was in the case of Coopérative des Agriculteurs de Mayenne. In that case, the Court relied on the Grand Chamber's finding in Bosphorus that the presumption of protection of Convention rights applied to the EC. With regard to the rebuttal

55 Bosphorus, supra n. 1 at para. 166.

56 ECJ, Case C-84/95 Bosphorus Hava Yollari Turizm ve Ticaret AS v Minister for Transport, Energy and Communications and Others [1996] ECR I-3953, at paras 25-6.

57 Peers, supra n. 13 at 454. 
of the presumption, the Court entered into a discussion of whether the aim pursued by the levy was legitimate and proportionate. For that purpose the Court referred to its decision in Procola $v$ Luxembourg, ${ }^{58}$ which dealt with a very similar levy. This approach suggests that the Court properly examined whether the levy was justified or not.

In Biret, the Court also relied on the Grand Chamber's finding that the protection offered by the Community is equivalent. In contrast to the case just mentioned, the Court only stated that in the present case there was no manifest deficiency in the protection of fundamental rights and quoted the case of Coopérative des Agriculteurs de Mayenne mutatis mutandis. ${ }^{59}$ The Court's approach appears to be rather superficial. No test was carried out. The reference to the case of Coopérative des Agriculteurs de Mayenne mutatis mutandis cannot act as a substitute for such a test as the only similarity between the two cases was that the claim was based on the applicant's property rights. The facts were not at all comparable. The cooperatives had to pay a levy for exceeding a milk quota whereas Biret went insolvent because it could no longer carry out its importing business because of an EC embargo against US beef. As the embargo had already been held to violate WTO law, there would have been ample reason for the ECtHR to engage with the question of whether an embargo in violation of WTO law can be a legitimate aim to restrict someone's property rights.

In contrast to Biret, the scrutiny carried out in Kokkelvisserij was much more in-depth. The applicant had argued that the protection afforded by the EU was manifestly deficient in the light of the Court's judgment in Vermeulen. ${ }^{60}$ The Court had found that the lack of a right to respond to the submissions made by the Belgian avocat général infringed the applicant's right to an adversarial trial under Article 6 of the ECHR. The Court then distinguished the situation before the ECJ in cases of a preliminary ruling, where there is a nexus between the domestic procedure and that before the ECJ, from the case in Vermeulen. In addition the Court pointed to the possibility of re-opening oral proceedings according to Article 61 of the ECJ's Rules of Procedure. The Court thus entered into an elaborate discussion as to why there was no manifestly deficient protection in the present case.

In a similar vein, in Gasparini the Court discussed in quite some detail why it was justified that the procedure before the NAB was not public. What was remarkable about Gasparini, however, was that the Court did not appear to fully apply the two stages of the Bosphorus test. Rather the Court jumped to the second stage of the test and examined whether in the present case the mechanism for conflict resolution was manifestly deficient. At no point in the 
judgment did the Court state that NATO generally offers a protection equivalent to that offered by the Convention. This is striking as the test of whether there was a manifestly deficient protection is designed to be a difficult one to meet. As the Court made it clear in Bosphorus, it requires a dysfunction of the mechanisms of control of the observance of Convention rights. Such a high threshold is only justified where the organisation normally offers an equivalent protection, so that the ECtHR can relax the intensity of its oversight. Only then can the ECtHR tolerate deficiencies in the human rights protection, which are not manifest. When establishing that the EU offered such an equivalent protection in Bosphorus, the ECtHR argued at length that this was the case. ${ }^{61}$ No such argument was made in Gasparini.

All in all, this short review of the ECtHR's case law reveals a mixed picture. It seems that the Court is generally willing to discuss the existence of a manifest deficiency in some detail. In Kokkelvisserij, Cooperative des Agriculteurs de Mayenne and Gasparini the Court entered into a short but convincing scrutiny of the merits of the case. Regrettably, in Biret no such test was carried out. There is no apparent reason for this.

\section{Discretion}

In Bosphorus, the Court made it clear that the presumption can only apply, where the Member State had no discretion in implementing European Union law:

It remains the case that a State would be fully responsible under the Convention for all acts falling outside its strict legal obligations. ${ }^{62}$

The immediate question was, of course, in what case a Member State must be deemed to have had discretion. Is this a purely formal question, so that each time there is an EU Directive a Member State's discretion must be assumed, since according to Article 288(3) TFEU (former Article 249 EC Treaty) directives are (only) binding as to the result to be achieved but leave the Member States the choice of form and methods? Or do we have to consider the exact content of each obligation arising from European Union law? Shortly after Bosphorus, the then President of the ECHR, Luzius Wildhaber, made it clear that the presumption only applied where the Contracting Party 'does no more than implement legal obligations flowing from its membership of the organisation.63 This statement confirms that the presumption was designed to apply to acts or omissions which only originated in EU law and where the Member

61 Bosphorus, supra n. 1 at paras $159-65$.

62 Ibid. at para. 157.

63 Wildhaber, 'The Coordination of the Protection of Fundamental Rights in Europe', Geneva 8 September 2005 (quoted by Costello, supra n. 9 at 100). 
States merely acted as agents for the EU. In Coopérative des agriculteurs de Mayenne, the Court expressly repeated the requirement that there be no discretion for the Member State for the presumption to apply. It highlighted that the Regulation which laid down the amount of the levy left no discretion to the Member State. Rather than merely pointing to the fact that the legal basis for the Member State's action was a Regulation, which the Member States do not have to transpose into national law but rather have to apply, the Court (albeit very briefly) looked at the substance of the Regulation and determined that the Member State had no choice. Given that the Court carried out a substantive test even though the act of EU law in that case was a Regulation, it seems as if the Court followed the rationale suggested by Wildhaber. This can be contrasted with Biret, where the Court did not mention the requirement that a Member State must not have any discretion. Rather, it applied the Bosphorus presumption without any comment to that effect, even though the legal basis for the embargo was contained in Council Directives. This decision can thus be understood in two different ways. Either the Court overlooked the requirement of a lack of discretion, or the Court was satisfied that the respondent State did not have any discretion and therefore left the requirement unmentioned. When looking at the exact legal basis for the embargo it becomes quite clear that the respondent State did not have any discretion when implementing it. Article 6 of the Directive states that 'Member States shall prohibit importation from third countries'. Thus the Court was correct in applying the presumption in this case. For the sake of clarity, however, the Court should have expressly referred to that requirement. The case law on this point is therefore not entirely clear. It is suggested, however, against the background of Wildhaber's statement and the Court's decision in Coopérative des Agriculteurs de Mayenne, that a substantive test must be carried out.

\section{Conclusion}

The Bosphorus and Matthews case law contradicted the traditional view in public international law that members of international organisations cannot be held responsible for acts or omissions by these organisations because they enjoy a legal personality distinct from that of their Member States. ${ }^{64}$ Therefore, the extension of the Behrami approach to cases where there was no domestic act or omission by a Contracting Party can be interpreted as a return to the more traditional view regarding the responsibility of Contracting Parties for acts and omissions committed by international

64 On this question cf. the very instructive article by Wilde, 'Enhancing Accountability at the International Level: The Tension Between International Organization and Member State Responsibility and the Underlying Issues at Stake', (2006) 12 ILSA Journal of International $\mathcal{F}$ Comparative Law 1 at $7-10$. 
organisations of which they are members. This distinction now seems to be well established. As a consequence of that case law, action taken by the EU under the Common Foreign and Security Policy will not be subjected to review by the ECtHR, as it will not involve acts or omissions by EU Member States but rather by the EU itself. This is especially relevant for future missions carried out in the framework of the EU's Common Security and Defence Policy. Violations of the ECHR by forces under the command of the EU will not be attributable to the Member States and any complaints directed against them will be held inadmissible by the ECtHR. The summary of the case law provided above has also revealed that there is still some inconsistency in the Court's case law involving the responsibility of member states for acts and omissions of international organisations. The cases of Gasparini and Biret could have been decided differently in light of the Matthews case. Moreover, the Court in Gasparini did not establish that the first stage of the Bosphorus test, the existence of an equivalent protection, was satisfied. Furthermore, in neither Boivin nor Connolly did the Court explain why it extended its Behrami reasoning to cases not concerning the UN.

Despite these shortcomings, the conditions for the applicability of the Bosphorus presumption have been clarified to some extent. An applicant must claim that there is either no equivalent protection of Convention rights at EU level, or that the protection in the instant case was manifestly deficient. In this context, it is remarkable that a manifest deficiency has not yet been found to exist.

Despite the clarifications found in the case law discussed, some points remain to be resolved. One question raised in particular by Gasparini is whether, apart from the EU and NATO, Member States of other international organisations will benefit from the presumption. A further point which will have to be addressed is whether the ECtHR will uphold the Bosphorus presumption after the EU has acceded to the ECHR and thus become a Party to it, just like its Member States. ${ }^{65}$

65 EU membership of the ECHR has become possible with the entry into force of Protocol No. 14 on 1 June 2010. On the future of the Bosphorus presumption, see Lock, 'The ECJ and the ECtHR: The Future Relationship between the Two European Courts', (2009) 8 The Law and Practice of International Courts and Tribunals 375 at 395-6. 